\title{
Monitoring of the Operating Parameters a Low- Temperature Fuel-Cell Stack for Applications in Unmanned Aerial Vehicles: Part I
}

\author{
Magdalena Dudek ${ }^{1,2^{*}}$, Andrzej Raźniak ${ }^{1,2}$, Bartłomiej Lis ${ }^{1,2}$, Tomasz Siwek ${ }^{1,3}$, \\ Bartosz Adamczyk ${ }^{1}$, Dagmara $\mathrm{Uhl}^{3}$, Wojciech Kalawa ${ }^{1}$, and Tadeusz $\mathrm{Uhl}^{2,3,4}$ \\ ${ }^{1}$ AGH University of Science and Technology, Faculty of Energy and Fuels, al. A. Mickiewicza 30, \\ 30-059 Kraków, Poland \\ ${ }^{2}$ AGH University of Science and Technology, Center of Energy, str. Czarnowiejska 36, \\ 30-059 Kraków, Poland \\ ${ }^{3}$ UAVS Poland Sp. z o.o. \\ ${ }^{4}$ AGH University of Science and Technology, Faculty of Mechanical Engineering and Robotics, \\ al. A. Mickiewicza 30, 30-059 Kraków, Poland
}

\begin{abstract}
The paper presents a brief analysis of the potential use of hydrogen-oxygen low-temperature fuel cells with proton-exchange membrane fuel-cell stacks as power sources for the construction of drive units powering unmanned aerial vehicles. Hydrogen storage methods are discussed. Characteristics of selected aspects of monitoring the electrical and non-electrical operating parameters of a drive unit with fuel cells were investigated, with respect to the fuel cell, fuel-cell cooling system, and gas reagent supplying the system with hydrogen and air. Hydrogen fuel consumption for the production of electricity and purification, or so-called purge, was analysed. Based on the results of laboratory tests of the parameters of a generator with fuel cells, an exemplary method of monitoring operating parameters and controlling power sources involving fuel cells is proposed.
\end{abstract}

\section{Introduction}

The main challenge for manufacturers of unmanned aerial vehicles (UAV) for civil and military applications is extension of flight time. Depending on the type of drone construction (airframe, multi-rotor), the approximate average UAV commercial flight time varies between 15 and $50 \mathrm{~min}$. Using hydrogen-oxygen fuel cells as energy sources for the construction of drive units may be one way to extend the flight time of drones [1-3].

Of three electrochemical energy sources (electrochemical batteries, supercapacitors, and fuel cells), hydrogen-oxygen fuel cells (FC) provide the greatest amount of available energy generated by a relatively light power system (FC stack + hydrogen tank + accessories supporting the operation of the energy generator). Compared to FCs, electrochemical batteries and (especially) supercapacitors are characterised by unfavourable energy density

\footnotetext{
* Corresponding author: potoczek@agh.edu.pl
} 
levels (i.e. the amount of energy stored in a given system per unit volume) or unfavourable parameters representing significant decreases in and discharges of voltage. However, their high power densities (power generated relative to device weight) constitute an advantage [4-6].

In order to extend flight time, research is increasingly being undertaken in the EU and worldwide on the use of fuel cells in designing power sources for UAV propulsion units [7-10]. Among the five well-known types of fuel cells, hydrogen-oxygen proton-exchange membrane fuel cells (PEMFCs), in particular, are already being used commercially in the construction of energy generators for powering drones. The following companies are among the best-known manufacturers of hydrogen-oxygen fuel cells for drone applications: i) Horizon/Hes, Singapore, ii) Ballard/Protonex, Canada, iii) EnergyOr Technologies, Canada, iv) BCH (Bing Cheng Hydron) China [11-15].

The option of using solid oxide fuel cells (SOFCs) for designing UAV electric power supply units is also worth mentioning. The use of SOFCs as energy sources is encouraging due to the potential for the use of not only hydrogen but also of easily available aviation fuels (kerosene, jet fuel) or other alternative fuels that can incorporate hydrogen [16-18].

Electric power fuel-cell generators consist of: a) a fuel-cell (FC) stack as a gas-electrical system of individual fuel cells, connected (via membrane electrode assembly, or MEA) with bipolar plates, b) a reagent dosing system (fuel and oxidiser), c) an FC-stack cooling system, d) a generator operation control system. Very often, fuel-cell generators are also equipped with an auxiliary energy source (e.g. electrochemical batteries) for powering auxiliary devices (e.g. cooling fans, monitoring and measurement instruments) [19-22].

Fuel cells (FCs), like batteries and accumulators, are galvanic cells; electric power is generated as a result of electrochemical reactions. However, unlike batteries, fuel cells operate as long as external reagents are supplied. In the case of hydrogen-oxygen fuel cells, the main factor determining the operating time of a FC generator is the amount of stored hydrogen fuel. Most often, hydrogen gas as fuel can be stored under pressures ranging from 200 to 700 bar in high-pressure composite tanks [23,24]. Prior to delivery to the anode space of the fuel cell stack, hydrogen pressure is reduced to the level required by the fuel cell manufacturer by means of reduction devices.

Other options include storing hydrogen at low pressure in solids (reversible metal hydrides, carbonaceous materials, etc.). It should be emphasised that these hydrogen storage technologies are in the development phase, although products in the form of 'hydrogen storage' dedicated to UAV are already available on the market [25-27]. Another interesting solution is the storage of hydrogen in the form of liquid fuels (methanol, ethanol) or chemical sources of hydrogen, so-called irreversible hydrides (e.g. $\mathrm{NaBH}_{4}$ ). In such cases, hydrogen is produced in the reactor on board the aerial vehicle. The advantage of this solution is the gain of a supply of humidified hydrogen fuel to the FC stack without any need for additional operations related to compressing or humidifying the gas [28-32].

A large number of reports regarding the use of PEMFCs to power UAV airframe or rotor models can be found worldwide. The following can be mentioned as examples of UAV airframe models with hydrogen-oxygen fuel cells: Antares DLR- $\mathrm{H}_{2}$ (Lange Aviation), Ion Tiger (U.S. Navy), Pterosoar (Horizon), HyFish (DLR, Germany), Mirador (DGA, France), Spider-Lion (AeroVironment, USA), and models such as those produced by the Georgia Institute of Technology (2006) and KAIST (2007). The flight time of UAVs powered by hydrogen gas ranges from 0.2 to approximately $6 \mathrm{~h}$ [33-36].

Successful attempts to use PEMFCs to power the electric motors of UAVs (mainly those with airframe designs) have encouraged the designers of rotor-type drones. A flight lasting over $4 \mathrm{~h}$ was made by a Hycopter powered by PEMFCs (Horizon, Singapore) [37]. EnergyOr Technologies Inc. from Canada presented a multi-rotor vehicle in which the use of PEMFCs enabled a flight over 2 hours long [38]. Other successful tests include those 
conducted by MMC, a Chinese manufacturer of drones, and Intelligent Energy, an English company incorporating fuel cells into UAV designs and extending flight times from 2 to more than 4 hours $[39,40]$.

Analysis of available technical data, including drone design, drone mission, lifting capacity, selection of a PEMFC stack, and methods of storing and using hydrogen for electric power generation, indicates variability in the energy efficiency of power units, which directly results in different operating times for FC generators in unmanned aerial vehicles, resulting in turn in different flight times.

One of the options for increasing the average energy efficiency of fuel cell generators and extending drone flight times is the development of appropriate algorithms for parameter control and energy management in these devices $[41,42]$.

Battery management systems (BMS), used to ensure the greatest possible energy density as well as to enhance the safety of battery use and the lifespan of cells used in battery packs, have been in development around the world for years. The main parameters being monitored are the battery's state of charge (SOC) and depth of discharge (DOD). This is accompanied by analysis of the state of the battery following operation compared with the state prior to operation (state of health $-\mathrm{SOH}$ ) $[43,44]$.

In the case of electric power FC generators, parameters for the control and monitoring of systems are much more complex than those for electrochemical batteries. In the case of FC generators, operation management systems must take into account not only the monitoring of electrical parameters such as voltage (U), current (I), power (P), and temperature distribution throughout the $\mathrm{FC}$ stack, but also the physicochemical parameters of the reagents (oxidiser and fuel) supplied to the FC generator. In the case of the aforementioned energy sources based on FC technology, it is also necessary to monitor the operating parameters of auxiliary systems that cover the device's so-called 'own' needs. The following are typical elements supporting the operation of the FC generator: i) FC stack cooling system, ii) FC purification (so-called purge), operation monitoring, and control of the entire power unit.

It should be emphasised that, unlike the BMSs of electrochemical batteries, FC generator power management systems are still in the development stage, notwithstanding the existing commercial applications of fuel cells in technology $[45,46]$.

The purpose of the study is to propose a methodology for the selection of experimental data from stationary tests of the power sources involving fuel cells that can be used for the development of operating parameter control algorithms and energy management of these devices. The study focuses in particular on the monitoring and analysis of electrical and non-electrical parameters of fuel-cell power sources essential for their use in the design of power units for unmanned aerial vehicles.

\section{Experimental part}

The test subject was a 2-kW hydrogen-oxygen PEMFC. This electric power range represents the power supply for various drone types (airframe, rotor). Fig. 1 shows a photograph of the PEMFC fuel cell stack (BCH 2000W) being tested in the laboratory. 


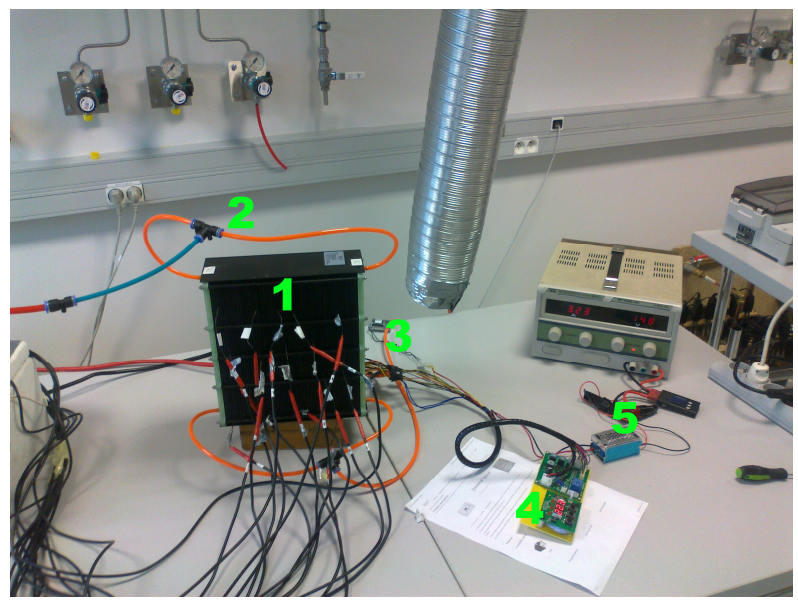

Fig. 1. Photograph of the FC stack (BCH 2000-W), along with all measurement and monitoring instruments, at the test stand. Numbers 1-5 indicate basic components required for normal operation of the device. 1 - PEMFC BCH 2000-W FC stack with metallic bipolar plates; view from air inlet side. On the opposite side of the device are four cooling fans that force air flow; 2 - tubes that deliver hydrogen to the top of the FC from both the left and right sides of the stack; 3 - outlet tubes that remove unused hydrogen from the FC from both the left and right sides of the bottom of the stack, equipped with solenoid purge valves at the end of each gas extraction tube; 4 - electronic controller for operation of the PEMFC BCH 2000-W stack; 5 - DC-DC converter (12-60 VDC IN - 12VDC, $6 \mathrm{~A}$ OUT) to the auxiliary devices of the FC power generator.

Table 1. Technical parameters of the BCH 2000-W PEMFC fuel-cell stack according to the manufacturer's specifications [47]

\begin{tabular}{|c|c|}
\hline Parameter & Value \\
\hline Number of individual MEA cells in FC stack & 65 \\
\hline Nominal $\mathrm{P}_{\text {nom }}$ and maximum electric power $\mathrm{P}_{\max }$ & $\mathrm{P}_{\text {nom }}=2000 \mathrm{~W}, \mathrm{P}_{\max }-$ no data available \\
\hline Recommended parameters of continuous operation $\mathrm{P}_{\text {nom }}$ & $36 \mathrm{~V} @ 56 \mathrm{~A}$ \\
\hline Weight of the complete FC generator & $2.5 \mathrm{~kg}$ \\
\hline Dimensions & $260 \times 235 \times 90 \mathrm{~mm}$ \\
\hline Hydrogen consumption & $28 \mathrm{Ndm}^{3} / \mathrm{min}$ \\
\hline Power supply of auxiliary devices for 'own' needs & DC-DC (12-60 VDC IN $-12 \mathrm{VDC}, 6$ A OUT $)$ \\
\hline
\end{tabular}

Based on the data presented in Table 1, the compact design of the FC stack and the light weight of the device $(<3 \mathrm{~kg})$ should also be noted. The factor enabling this favourable design and these weight parameters for UAV applications is the use of bipolar metal instead of traditional graphite plates in the construction of the stack. This enabled reduction of the length by over $20-30 \%$ and the weight by $30-40 \%$ in relation to an FC stack with graphite plates [48]. PEMFCs with bipolar metal plates appear suitable for UAV applications. 


\section{Test equipment and methodology}

Fig. 2 shows a test stand for the determination of operating parameters of the $\mathrm{BCH}$ 2000-W PEMFC stack.

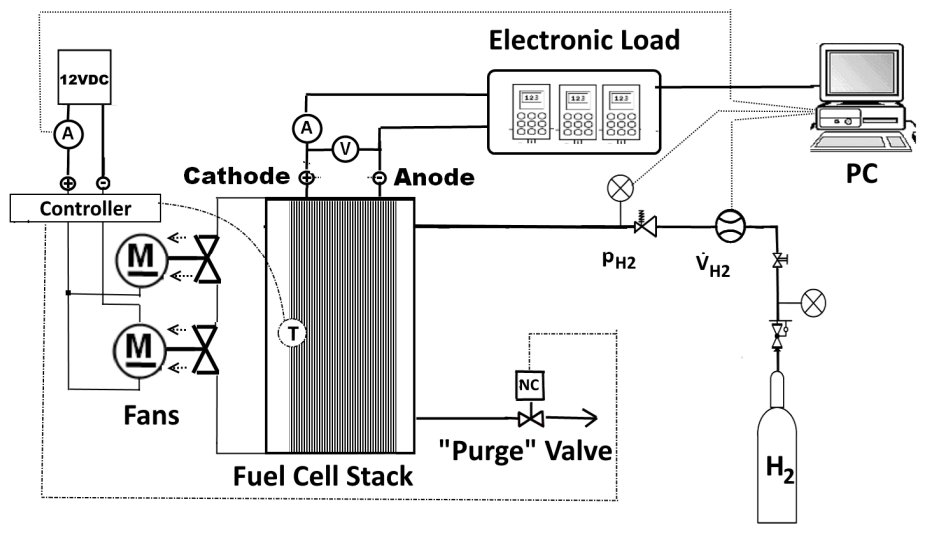

Fig. 2. Schematic diagram of the test stand for determination of the electrical and non-electrical parameters of the BCH 2000-W PEMFC stack

First, hydrogen from a high-pressure steel cylinder (Air Liquide ALPHAGAZ $1 \mathrm{H} 2$, purity 5.0) was delivered to the BCH 2000-W FC stack. Before entering the anode space of the FC stack from the gas installation, the hydrogen pressure was reduced in two steps: a) by means of a mechanical pressure regulator from high pressure (HP, $p=10-300$ bar) to medium pressure (MP, $\mathrm{p}=5-10 \mathrm{bar}$ ); b) by means of a Bronkhorst P-602CV pressure stabiliser, used to maintain the desired pressure of $\mathrm{p}_{\mathrm{H} 2}=0.5$ bar for hydrogen delivered to the anode space of the FC stack. The curve of the hydrogen pressure stabilisation process was recorded on a $\mathrm{PC}$ at a recording frequency of $10 \mathrm{~Hz}$.

The BCH 2000-W FC stack operates in the so-called open-cathode configuration. The air for cooling the FC stack and for electrochemical reactions is supplied through holes in the bipolar plates. This device operates in the so-called closed-anode configuration, meaning that the hydrogen outlet from the FC is normally closed ( $\mathrm{NC}$ - normal close) by means of a solenoid purge valve. To purge the anode side of the FC stack, the valve is opened frequently by the stack controller. During the operation of the stack, auxiliary devices (cooling fans, solenoid valves, monitoring and measurement systems) were powered by a laboratory DC power supply via a step-down converter which reduced voltage to 12 VDC. The amount of electric power consumed by the auxiliary devices representing the so-called 'own' needs of the FC stack were recorded using a PowerLog 6S data logger.

The electrical parameters of the $\mathrm{BCH} 2000-\mathrm{W}$ FC stack were determined using a Chroma 63202 electronic load $(2600 \mathrm{~W} / 0-50 \mathrm{~A} / 0-600 \mathrm{~V})$ for a current range from 0-50 A (power $<2 \mathrm{~kW}$ ); for higher currents (I $>50 \mathrm{~A}$ ), an additional resistive load was used. Voltage measurements were made with an Agilent $34410 \mathrm{~A}$ voltmeter (6.5 digits), current measurements with an Agilent 34411A multimeter (6.5 digits) using a $150 \mathrm{~A} / 60 \mathrm{mV}$ current shunt. Measurement data was recorded on the PC with dedicated software.

During the electrical tests of the $\mathrm{BCH} 2000-\mathrm{W}$ FC stack, the temperature of the stack was also monitored by means of a 16-channel $\mathrm{TCH}-16$ thermometer connected to the PC; $15 \mathrm{~J}$ type thermocouples, evenly spaced along the cooling air inlet to the FC stack and 
consisting of 65 individual MEAs connected in series, were used. Measurement conditions: air temperature in the laboratory $20-25^{\circ} \mathrm{C}$, relative air humidity: $30-50 \%$.

Fig. 3 shows the hydrogen storage installation in ultralight composite tanks.

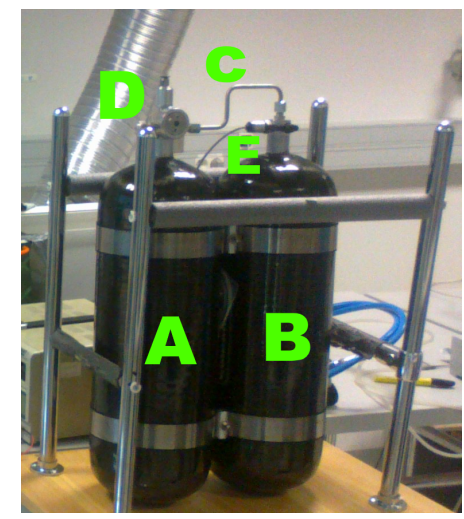

Fig. 3. Photo of connections between ultralight composite hydrogen tanks and pressure fittings

During the electrical tests of the $\mathrm{BCH} 2000-\mathrm{W}$ FC stack's hydrogen fuel storage, two LC12.0-30A composite tanks (A and B) were used, with a capacity of $12 \mathrm{Ndm}^{3}$ each and permissible hydrogen pressure up to 400 bar (Fig. 3). The ultralight tanks (A and B) were connected in parallel with steel tubes $(\mathrm{C})$ with one pressure regulator $(\mathrm{D}$; a single-stage $\mathrm{HP} / \mathrm{MP}$ pressure regulator (HP - high pressure, $\mathrm{p}=350-400$ bar, MP - medium pressure, $\mathrm{p}=5-10$ bar) and a pressure sensor (E) for hydrogen stored inside the composite tanks. An electronic pressure sensor and an electronic pressure regulator (from MP, $\mathrm{p}=10$ bar to LP low pressure, $\mathrm{p}=0.5$ bar), linked directly to the anode space of the BCH 2000-W FC stack, were connected to the system.

\section{Test results and discussion}

\subsection{Description of the operating parameters of the 2-kW FC stack}

The main factor determining the suitability of an FC stack as the main component for designing power generators is the electric power that the device can deliver to the drive unit or other electric power collector.

Each galvanic cell, or FC stack, has maximum power points with corresponding pairs of (voltage-current $)_{\max }$ parameters. For some types of galvanic cells, this point may not be visible on the power (P)-current (I) curve (as often happens in the case of primary cells), because it is positioned beyond the operational voltage or current. In the case of FC generators, the location of the (voltage-current) max $_{\max }$ point is usually clearly identified and plays an important role during operation of the generator. The gradual loading of the FC stack causes self-adjusting changes in its operating conditions (reductions in voltage, increases in current and in the consumption of hydrogen fuel) which result in a corresponding increase in the power drawn from the stack, in accordance with growing demand. The device operates effectively until it reaches the maximum power point. Once it exceeds this point, the power delivered by the FC stack drops rapidly despite the increasing current load [49]. In cases of uneven demand for power over time, a frequently used method of adjusting the power balance is the use of an auxiliary system in the form of peak batteries or supercapacitors $[50,51]$. 
Fig. 4 shows voltage (U)-current (I) and power (P)-current (I) curves determined for the tested 2-kW FC stack (BCH, China) within the manufacturer's nominal power specifications.

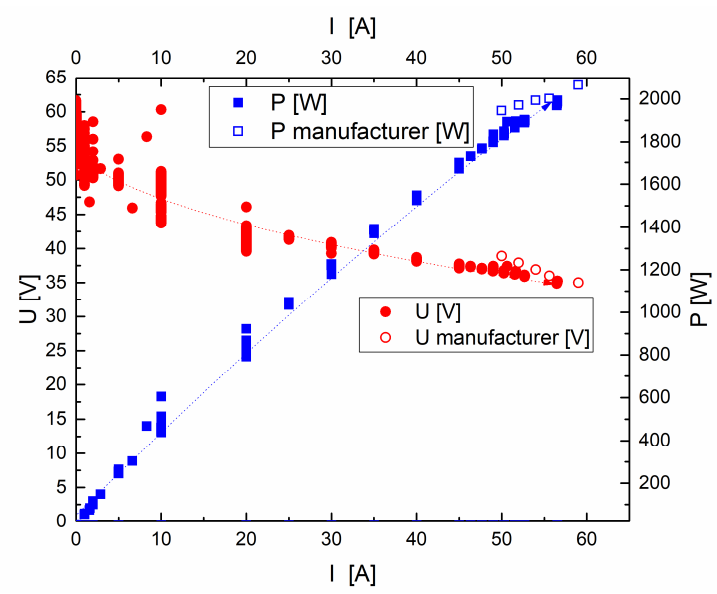

Fig. 4. Voltage (U)-current (I) and power (P)-current (I) curves determined for a 2000-W PEMFC stack within recommended operational parameters (nominal power)

Based on the determined U-I and P-I curves, it can be concluded that, along with an increase in current (I), the electric power (P) drawn from the FC stack increases while the voltage $(\mathrm{U})$ at the terminals decreases. In the initial part of the current-voltage curve for current up to $10 \mathrm{~A}$, a rapid voltage decrease, from $\mathrm{U}_{\mathrm{ocv}}=\mathrm{E}=65 \mathrm{~V}$ (ocv $=$ open circuit voltage) to $50 \mathrm{~V}$, can be observed; this is related to the activation losses prevailing in the operating range of this FC. For current values from 10 to $60 \mathrm{~A}$, linear voltage decreases due to ohmic losses in the internal resistance of the FC stack prevailing in this part of the $\mathrm{U}=\mathrm{f}(\mathrm{I})$ curve. At the same time, a gradual increase can be observed in the power $\mathrm{P}$ drawn from the FC stack, to approximately $2 \mathrm{~kW}$ for a current (I) of $57 \mathrm{~A}$ and a voltage of (U) 35 V. Fig. 4 also shows selected P-I curve points of the BCH 2000-W FC stack as specified by the manufacturer. As shown in Fig. 4, the determined values of U, I, and P agree closely with the data received from the manufacturer. Electrical test results confirm the correct operation of the BCH 2000-W FC stack over the entire range of specified current load.

An important factor in designing an FC-stack operation control system is the monitoring of FC operating parameters with a view to the cell's durability and safety. These parameters include voltage control from OCV to the minimum permissible voltage (about half of OCV), maximum permissible current, and maximum power, since the FC stack has no overload capability and, after exceeding the maximum power point $\mathrm{P}_{\max }$, generates more heat than electric power. This can lead to an undesirable temperature increase. The task of the control system is to monitor the permissible voltage $(\mathrm{U})$ within a range from an OCV of 65 to approximately $28 \mathrm{~V}$, corresponding to the $\mathrm{P}_{\max }$ value. After exceeding this value, the control device should disconnect the FC stack.

In the case of transport and aviation applications, analysis of the impact of the positioning of the FC generator plays an important role. Correct positioning of the FC stack must enable not only access of the reactants to each PEMFC cell, but also effective removal of water and other impurities from the anode space while the cell is being flushed with hydrogen.

During operation of the FC stack, the purge valve and the hydrogen outlet should be placed in the stack's lowest possible gravitational position. Due to UAV design 
requirements, the FC generator orientation most often considered is either horizontal or vertical. Fig. 5 shows the voltage (U)-current (I) and power (P)-current (I) curves for the BCH 2000-W FC stack in vertical or horizontal orientation.

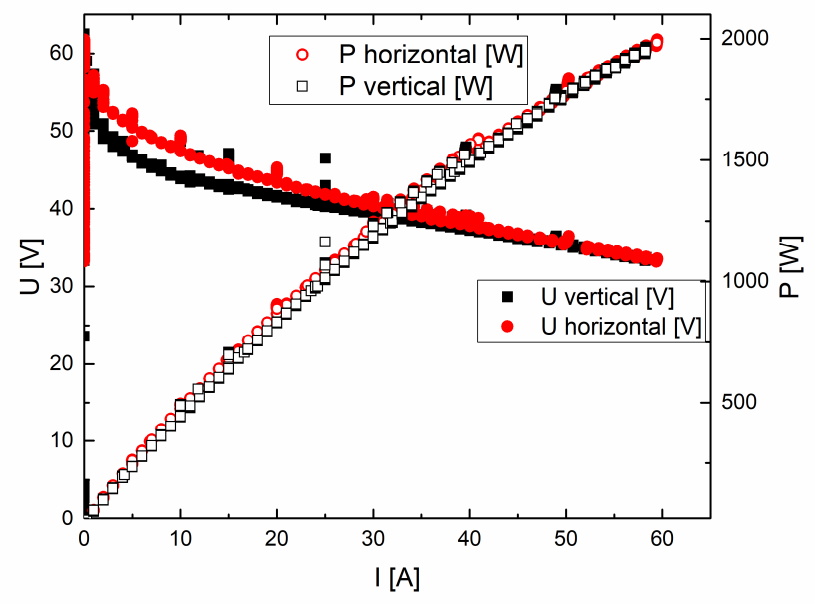

Fig. 5. Voltage (U)-current (I) and power (P)-current (I) curves determined for an FC stack operating in vertical or horizontal orientation

Fig. 5 shows the voltage (U)-current (I) and power (P)-current (I) curves for the tested PEMFC stack with either a vertical or horizontal orientation while being loaded with current which gradually increases from 0 to 60 A. The curve in Fig. 5 shows that, along with increases in the current and load, the electric power drawn from the FC stack increases while the voltage at the terminals decreases. Power P drawn from the FC stack increases to $\sim 2 \mathrm{~kW}$. Based on the U-I and P-I curves determined in the tested configurations of the device's orientation (horizontal or vertical), it can be concluded that changing from a vertical to a horizontal orientation does not affect the electrical parameters of the PEMFC stack.

The use of an FC stack as a power unit requires operation at stable values of current (I), voltage (U), and power $(\mathrm{P})$ in accordance with the requirements of a powered electrical consumer.

Fig. 6 shows voltage $(\mathrm{U})$, current $(\mathrm{I})$, and power $(\mathrm{P})$ curves recorded under variable current load for the BCH 2000-W FC stack in horizontal orientation. As shown in Fig. 6, the FC stack is characterised by stable operation parameters at a nominal power of approximately $2 \mathrm{~kW}$. Within a range from 2530 to $2750 \mathrm{~s}$, no decrease is noted in the device operation parameters; such a decrease might result, for example, from water deposition in the FC stack (which would be indicated by a decrease in voltage and current drawn from the device), confirming that the process of purging the anode side of the stack and removing water and nitrogen is sufficient. If any of the limit parameters are exceeded, e.g. after exceeding the maximum power point, the controller monitoring the $\mathrm{FC}$ stack operating parameters $\left(\mathrm{U}>32 \mathrm{~V}, \mathrm{I}<65 \mathrm{~A}, \mathrm{P}<2000 \mathrm{~W}, \mathrm{~T}<65^{\circ} \mathrm{C}\right)$ should disconnect the overload from the stack to prevent it from damage. If increased instantaneous power is required, it should be delivered by a buffer auxiliary power source (e.g. battery pack) to ensure continuity of power supply to the UAV's electric motors. 


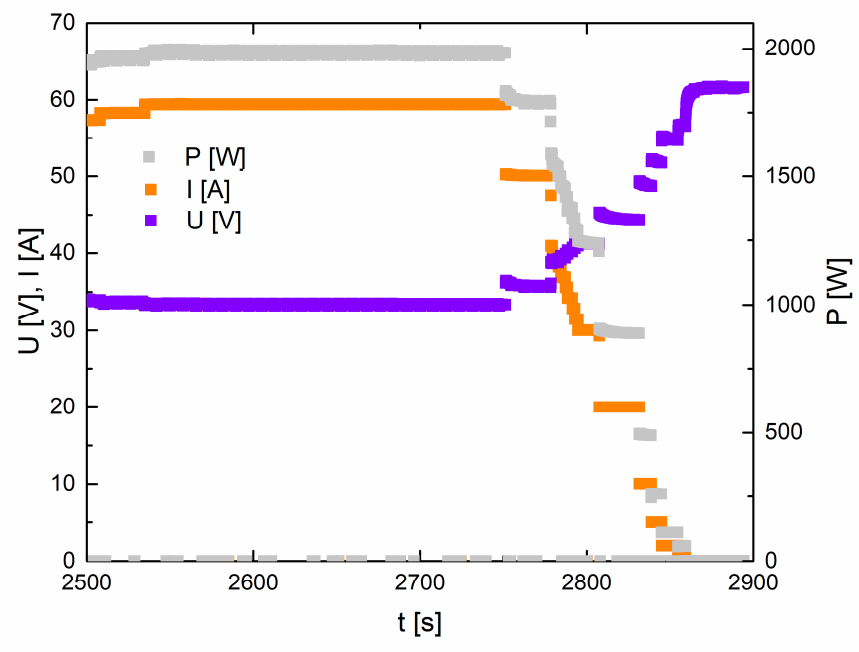

Fig. 6. Voltage (U), current (I), and power $(\mathrm{P})$ curves recorded under a variable current load for a fuel cell stack BCH $2000-\mathrm{W}$ in horizontal orientation

Another important parameter for the correct operation of the device and its long-term lifespan is the temperature distribution during electrical operation of the power source under variable electrical load.

In Fig. 7, variations in the temperature of the $\mathrm{BCH} 2000-\mathrm{W}$ PEMFC stack were determined using type $\mathrm{J}$ thermocouples, which were evenly spaced in individual cells of the BCH 2000-W FC stack as shown in Fig. 1. Temperature measurements were made during gradual loading of the device at the electrical values shown in Fig. 4.

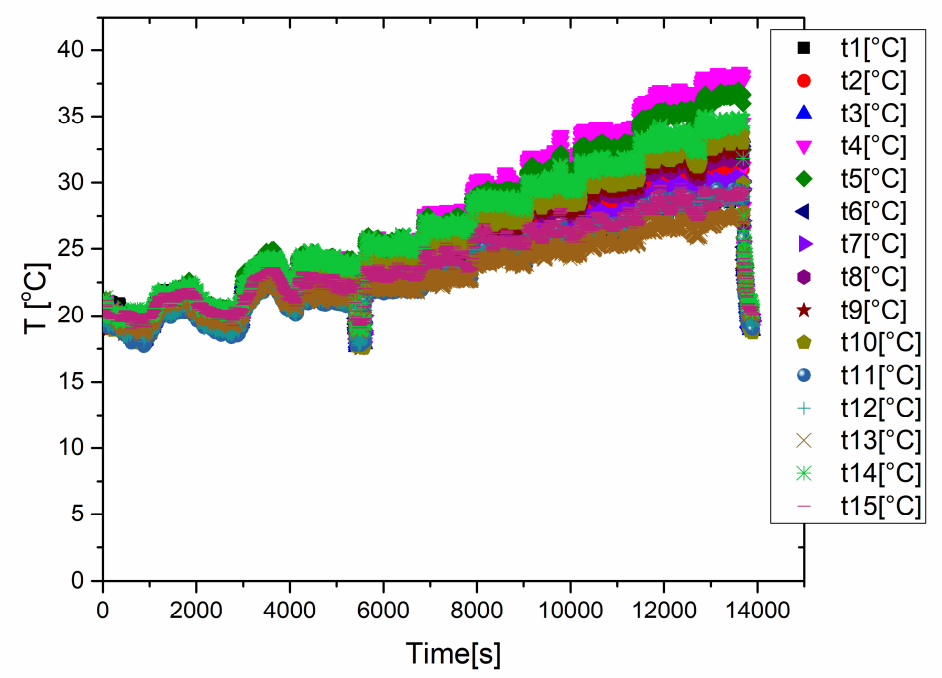

Fig. 7. Variations in temperature (t1-t15) of the PEMFC BCH $2000-\mathrm{W}$ stack during operation under variable current load 
As shown in Fig. 7, an increase in electrical load causes an increase in temperature, which must be reduced by means of a cooling medium. The highest temperature during operation of the FC stack was approx. $40^{\circ} \mathrm{C}$, a very safe temperature which falls within the range recommended for the electrical operation of the $\mathrm{FC}$ stack, i.e. $50-65{ }^{\circ} \mathrm{C}$. A temperature increase in PEMFCs with Nafion membranes may cause moisture loss, which leads to an increase in electrical resistance inside the cells [53]. As shown in Fig. 7, the temperature gradient between individual PEMFC cells is approximately $15{ }^{\circ} \mathrm{C}$. A gradient above $20^{\circ} \mathrm{C}$ may be a factor in reducing the effectiveness of the FC stack. The temperature distribution in individual PEMFCs is an important parameter for the control system of the FC generator.

In addition to electric power, waste heat and water vapour are also produced by the FC stack. The efficiency of the conversion of hydrogen into electric power by the stack is $\sim 45$ to $65 \%$; waste heat must be removed from the surface of the fuel cells. As the power generated by the FC stack increases, the temperature also increases [53,54].

\subsection{Investigation of PEMFC stack performance and energy requirements for the supply of auxiliary devices as integral parts of the analysed power source}

The next stage of tests to be carried out in order to design a control and energy management system in a PEMFC stack consists of the analysis of electrical parameters and energy demand for supplying auxiliary devices.

Fig. 8 shows the variation in electrical parameters such as the current (I), voltage (V), and power (P) drawn by auxiliary devices during the operating time of the $\mathrm{BCH} 2000-\mathrm{W}$ PEMFC stack.

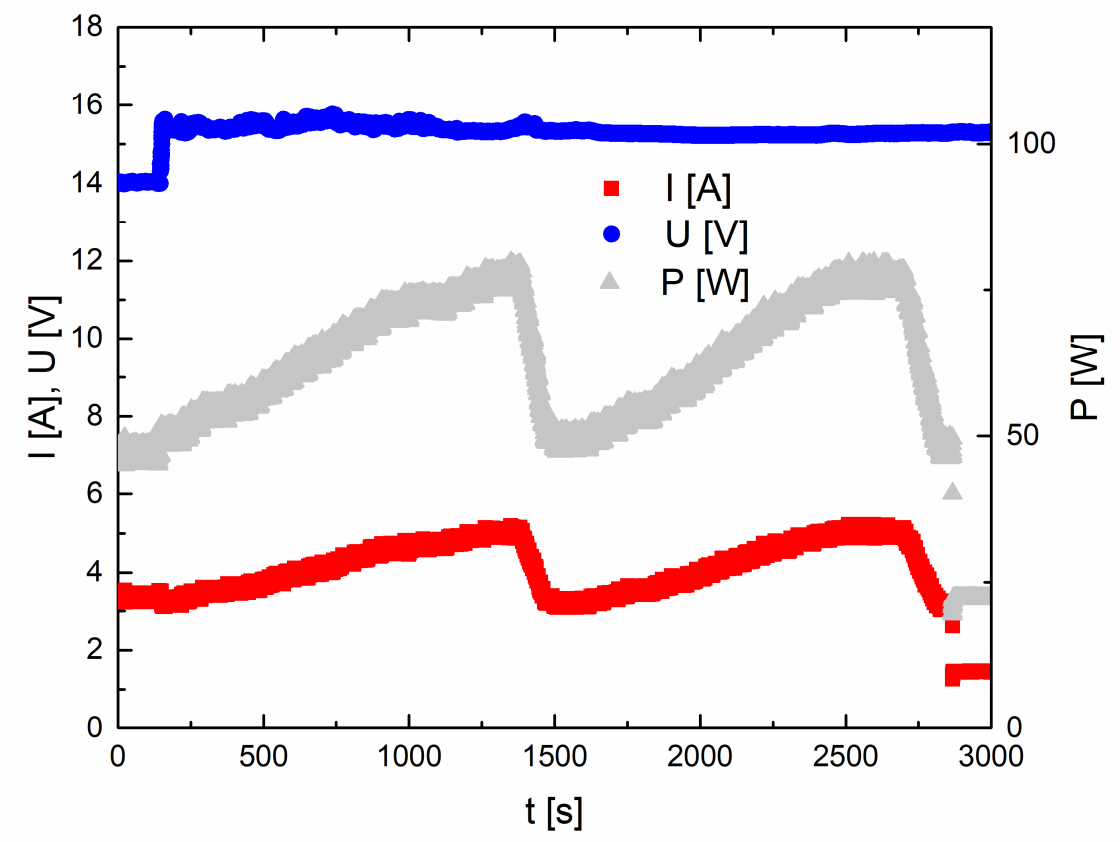

Fig. 8. Variations in the current (I), voltage (V), and power $(\mathrm{P})$ drawn by auxiliary devices during the operating time $(\mathrm{t})$ of the FC stack 
It can be concluded that the demand for power drawn to supply the DC/DC converter adjusting the electrical parameters of auxiliary devices for the BCH 2000-W PEMFC stack amounts to at least $50 \mathrm{~W}$ without load and increases to $80 \mathrm{~W}$ during maximum load to approximately $2000 \mathrm{~W}$. This is directly related to the increase in electrical power used by the cooling system responsible for delivering increasing amounts of cooling air in order to dissipate heat generated by the PEMFC stack during operation under load.

Fig. 9 shows power demand $\left(\mathrm{N}_{\mathrm{el}}\right)$, which depends on the cooling air flow rate $(\mathrm{V})$, on which the pressure losses $\left(\Delta \mathrm{p}_{\text {str }}\right)$ depend in turn.

Pressure losses $\left(\Delta \mathrm{p}_{\text {str }}\right)$ were determined for the cooling device (fan), as well as for the air flowing through the channels in the bipolar plates of the FC stack.

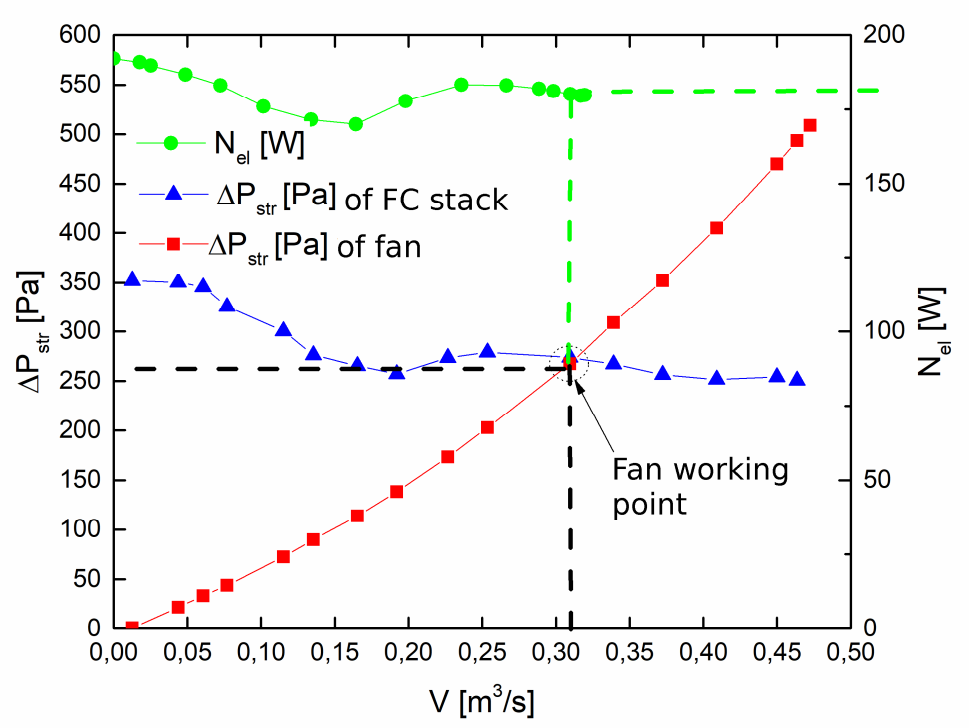

Fig. 9. Flow characteristics of the PEMFC stack's cooling device: fan system and electric power demand $\left(\mathrm{N}_{\mathrm{el}}\right)$ depending on the cooling air flow rate $(\mathrm{V})$.

In order to determine the demand for electric power $\mathrm{N}_{\mathrm{el}}$ required to run the cooling fans, the working point of the cooling device was determined, taking into account the flow resistance through the channels in the bipolar plates of the BCH 2000-W PEMFC stack. As shown in Fig. 9, the working point of the system comprising the BCH 2000-W FC stack and cooling fans is located at the intersection of the curve of flow resistance generated by the stack (Fig. 9, red line) and the fan performance curve (Fig. 9, blue line).

As shown in Fig. 9, the working point of the fans at their maximum rotational speed is at the air flow rate $\mathrm{V}=0.31 \mathrm{~m}^{3} / \mathrm{s}$, which corresponds to $\Delta \mathrm{P}_{\text {str }}=260 \mathrm{~Pa}$. Based on the working point of the system comprising the FC stack and cooling fans, the electric power required to power the cooling devices was determined. The electric power $\mathrm{N}_{\mathrm{el}}$ was $180 \mathrm{~W}$ at the highest possible level of cooling performance.

Based on the experimental data presented in Fig. 8 on variations of current (I), voltage $(\mathrm{U})$, and power $(\mathrm{P})$ over time $(\mathrm{t})$, it was found that, in the case of a PEMFC stack with an electric power of approximately $2000 \mathrm{~W}$, the electric power required for auxiliary devices is approximately $80 \mathrm{~W}$.

On the basis of the flow curve of the cooling device presented in Fig. 9, it is estimated that approximately $180 \mathrm{~W}$ of power is supplied to the cooling devices. This shows that the cooling devices in current use have a double supply of electric power. 


\section{Summary}

In the first part of the paper, we presented an analysis of the electrical parameters of a PEMFC stack as well as the electrical energy consumed during operation of the PEMFC stack. This study was focused on the elaboration of the experimental methodology necessary to obtain electrical parameters and to develop monitoring and measurement systems for the power sources of a PEMFC stack. The method of analysis of variations in electrical parameters such as voltage, current, and electrical power generated by a PEMFC stack and collected by the fuel cell generator's auxiliary devices were presented in order to develop algorithms (part II) for controlling the operating parameters of the relevant power sources.

The study was carried out under the auspices of the National Centre for Research and Development (NCBR) POIR.01.01.01-00-0682/17, 'Extending flight duration of unmanned aerial vehicles (UAV) through the use of hybrid energy sources', financed in the period 2017-18.

\section{References}

1. M. Hassanalian A. Abdelkefi, , Prog. Aerospace Sci. 91, 99 (2017)

2. T. Donateo, A. Ficarella, L. Spedicato, A. Arista, M. Ferraro, Appl. Energ. 187, 807 (2017)

3. S.J. Kim, G.J. Lim, J. Cho, Comput. Ind. Eng. 117, 291 (2018)

4. M. Broussely, G. Pistoia (eds) Industrial application of batteries: from cars to aerospace and energy storage (Elsevier, 2010)

5. F. Ustolin, R. Taccani, Int. J. Hydrogen Energ. 43, 11853 (2018)

6. B.G Gang, S.Kwon, Int. J. Hydrogen Energ. 43, 9787 (2018)

7. A. Gong, D. Verstrate, Int. J. Hydrogen Energ. 42, 21311 (2017)

8. N. Belmonte, S. Staulo, S. Fiorot, C. Luetto, P. Rizzi, M. Baricco, Appl. Energ. 215, 556 (2018)

9. P. Bogusz, M. Korkosz, P. Wygonik, M. Dudek, B. Lis, Prz. Elektrotechniczn. 5, 139 (2015)

10. W. Vielstich, H. Yokokawa, H.A.Gasteiger, (eds) Handbook of Fuel Cells, Fundamentals, Technology and Apllications, (New York, Wiley 2009)

11. Horizon launches Hycopter fuel cell multirotor UAV, Fuel Cells Bulletin 2015, (iss. 5), 4 (2015)

12. US Navy orders 13 Protonex fuel cells to power UAV field trials, Fuel Cells Bulletin 2018, (iss. 7), 4 (2018)

13. EnergyOr shows off world's first fuel cell multirotor UAV, Fuel Cells Bulletin 2015, (iss. 4), 5 (2015)

14. Intelligent Energy shows modular tech for commercial UAVs, Fuel Cells Bulletin 2018, (iss. 5), 4 (2018)

15 Chinese UAV maker MMC flies hydrogen fuel cell drone for $4 \mathrm{~h}$, Fuel Cells Bulletin 2016, (iss. 6), 4 (2016)

16. Korean researchers create miniaturised SOFC to power drones, Fuel Cells Bulletin 2016, (iss. 4), 5 (2016)

17. UK funding for Ceres SOFC range-extender, PEM electrode R\&D, Fuel Cells Bulletin 2016, (iss. 4), 3 (2016)

18. T. Labreche, Solid oxide fuel Cells power systems for small UAVs, Joint Service Power Expo 24-26 April 2007 San Diego.

19. J. Larminie, A. Dicks, Fuel cell systems explained, (Chichester, John Wiley \& Sons, 2000) 
20. M. Dudek, P. Tomczyk, P. Wygonik, M. Korkosz, P. Bogusz, B. Lis, Int. J. Electrochem. Sc. 8, 8442 (2013)

21. M. Dudek, A. Raźniak, B. Lis, M. Kawalec, M. Krauz, T, Wójcik, E3S Web Conf. 14, 2267 (2017)

22. Ch. Yang, S. Moon, Y. Kim, , J. Mech. Sci. Technol. 30, 2379 (2016)

23. L. Wang, Ch. Zheng, S. Wei, B. Wang, Z. Wei, Int. J. Hydrogen Energ. 40, 6853 (2015)

24. G.W. Mair, B. Becker, S. John, E. Duffner, Int. J. Hydrogen Energ. (2018) (in press) doi.org/10.1016/j.ijhydene.2018.04.068

25. I. Sreedhar, K. M. Kamani, B. M. Kamani, B M. Reddy A. Venugopal, Renew. Sust. Energ. Rev. 91, 838 (2018)

26. S.H. Chan, J.P. Stempin, O. Ding, P. Su, H. Ho, , Int. J. Hydrogen Energ. 41, 13869 (2016)

27. Cella Energy, Israel Aerospace Industries work on fuel cell UAV, Fuel Cells Bulletin 2015 (iss. 8) 3 (2015)

28. T. Kim, Energy 69, 721 (2014)

29. T. Kim, S. Kwon, Int. .J. Hydrogen Energ. 37615 (2012)

30. S. Zhang, Y. Zhang, J. Chen, C. Yin, X. Liu, J. Power Sources 389, 37 (2015)

31. S. Chandra, S. Lal, V. M. Janardhanan, K. Ch. Sahu, M. Deepa, J. Power Sources 396, 725 (2018)

32. J. Wang, H. Wang, Y. Fan, Engineering 4, 352(201)

33. DLR, Lange Aviation to develop Antares H3 fuel cell aircraft, Fuel Cells Bulletin 2010, (iss. 9) 4 (2010)

34. NRL completes first flight of Ion Tiger with custom fuel cell, Fuel Cells Bulletin, 2010, 5 (2017)

35. Hydrogen fuel cells power Georgia Tech UAV, Fuel Cells Bulletin 10 (2006) 5-6

36. C. Herwerth, C. Chiang, A. Ko, S. Matsuyama, et all, Development of a small long endurance hybrid PEMFC fuel cell powered UAV, SAE Technical Paper 2007-013930, (2007)

37. Horizon launches Hycopter fuel cell multirotor UAV, Fuel Cells Bulletin, 2015 (iss. 6) $4(2015)$

38. EnergyOr fuel cell multirotor drone in $2 \mathrm{~h}$ flight with camera, Fuel Cells Bulletin 2016 (iss. 2),3 (2016)

39. Intelligent Energy fuel cells significantly boost drone flight time, Fuel Cells Bulletin 2016, (iss. 1), 4 (2016)

40. E. Lechartier, E. Laffly, M.C. Péra, R. Gouriveau, D. Hissel, N. Zerhouni, Int. J. Hydrogen Energ. 40, 8384 (2015)

41. J. Mitzel, E. Gülzow, A. Kabza, J. Hunger, S.S. Araya, P. Piela, I. Alecha, G. Tsotridis Int. J. Hydrogen Energ. 41, 21415 (2016)

42. Ch.Y. Chen, K.P. Huang, W.M. Yan, M.P. Lai, Ch.Ch. Yang, , Int. J. Hydrogen Energ. 41, 11784 (2016)

43. B. Kumar, N. Khare, P.K. Chaturvedi, Microelectron. Reliab. 84, 66 (2018)

44. W. Sung, J. Lee, Comput. Chem. Eng. 117, 283 (2018)

45. J.J. Cheng Y.Ch. Hsu, J. Taiwan Inst. Chem. E. 73, 102 (2017)

46. K. Nikiforow, P. Kosk J. Ihonen, , Int. J. Hydrogen Energ. 2616760 (2017)

47. Specification of the manufacturer, China www.icecity-js.com (2018.09.18)

48. A. Mahdavi, A. Ranjbar, M. Gorji, M. R. Esbo, Appl. Energy 228, 656 (2018)

49. H. Fathabadi, Renew. Energ. 130, 714 (2019)

50. Y. Zhan, Y. Guo, J. Zhu, L. Li, Int. J. Elec. Power 67, 598 (2015)

51. H. Fathabadi, Energy 143, 467 (2018) 
52. K. H. Kim, K.Y Lee, S.Y.Lee, E.A.Cho,T.H.Lim, H.J. Kim, S.P.Yoon, S. H. Kim, T. W. Lim, J.H. Jang, Int. J. Hydrogen Energ. 23,13104 (2010)

53. M. Adamiec, Prz. Elektrotechniczn. 11a, 334 (2018)

54. P.J Swornowski, Prz. Elektrotechniczn., 4a,176 (2012) 